\title{
Türkiye'de Elektronik Belgelerin Geleceği İçin Ulusal Strateji İhtiyacı: Literatüir Işığında Bir İnceleme
}

\section{Need for a National Strategy for the Future of Electronic Records in Turkey: A Review of the Literature}

\author{
Niyazi Çiçek ${ }^{1}$ []
}

'Prof. Dr., İstanbul Üniversitesi, Edebiyat Fakültesi, Bilgi ve Belge Yönetimi Bölümü, İstanbul, Türkiye

ORCID: N.Ç. 0000-0002-9868-242X

Sorumlu yazar/Corresponding author: Niyazi Çiçek,

İstanbul Üniversitesi, Edebiyat Fakültesi, Bilgi ve Belge Yönetimi Bölümü, İstanbul, Türkiye E-posta: ncicek@istanbul.edu.tr

Bașvuru/Submitted: 04.05.2021 Revizyon Talebi/Revision Requested: 29.05.2021 Son Revizyon/Last Revision Received: 02.06.2021 Kabul/Accepted: 05.06.2021

Online Yayın/Published Online: 25.06.2021

Atıf/Citation: Çiçek, N. (2021). Türkiye'de elektronik belgelerin geleceği için ulusal strateji ihtiyacı: Literatür 1șığında bir inceleme. Bilgi ve Belge Araştırmaları Dergisi, 15, 33-57. http://doi.org/10.26650/bba.2021.15.02

\section{ÖZ}

Hızla gelişen dijital çağda elektronik belgelerin geleceğiyle alakalı belirsizlikler henüz giderilmiş değildir. Bu belgelerin uzun süre muhafaza edildikten sonra özniteliklerinin korunarak ilk üretildiği gibi aynı özgünlükte bulunup bulunamayacağı konusu tartışılmaya devam etmektedir. Gelişmiş ülkelerde öngörülebilir politika belirleme gayretleri bulunsa da birçok ülkede olduğu gibi Türkiye'de de çalışmalar henüz yeterli olgunluğa ulaşmamıştır. Oysa kurumların bilgi teknolojisi yatırımları arasında özellikle elektronik belge yönetimi sistemleriyle alakalı projelere yüklü miktarda kaynak ayırdıkları bilinmektedir. Buna karşın yatırımlar neticesinde oluşan e-belgelerin uzun vadede erişim ve kullanım koşulları ne yazık ki çok da planlanmamaktadır. Bu çalışmada e-belgelerin geleceği konusunda başta ülke, ardından kurumlar düzeyinde uygulanabilir çözümler barındıran ulusal ölçekte strateji ihtiyacı daha önce yapılmış bilimsel çalışmalar ışı̆̆ında tartışılmaktadır. Nitel araştırma yönteminin kullanılıp durum tespiti anlayışının benimsendiği bu makalede literatüre dayalı bir inceleme yapılmıștır. Literatür taranarak elde edilelen veriler doküman analizi tekniği ile değerlendirilmiştir. Bilgi güvenliği standardı kapsamında politikalar geliştirilmeye çalıșılmasına rağmen konu bilginin de ötesinde belge güvenliğiyle alakalıdır. Aksi halde örgütlerdeki bilgi varlıkları olan belgelerin yok olması gibi telafisi mümkün olmayan riskler bizi beklemektedir. Her ne kadar birlikte çalıșabilirlik esasları ve standartlar șeklinde rehberler çıkarılmış olsa da tüm bunlar e-belgelerin bütünlüğü, e-imzanın uzun sure korunması, dijital devamlılı̆̆ kurumların politika üretmesine yetmemektedir. Alanla ilgili otorite kurumların bu belgelerin sürdürülebilirliğiyle alakalı stratejiler geliştirmesi gerekmektedir.

Anahtar kelimeler: Elektronik belge yönetimi, Arşivlenen e-belge, e-Belge stratejisi, Dijital arşivler

\section{ABSTRACT}

In this rapidly developing digital age, uncertainties regarding the future of electronic (e)records have not yet been resolved. It is still debatable whether these records can be found in the conditions that they were produced in, their original nature preserved even after being stored for a long time. Despite efforts to establish predictable policies in developed countries, studies concerning the future of e-records in Turkey, like in many other countries, have not yet reached sufficient maturity. It is known that government institutions have allocated a large amount of resources to projects related to e-records among their information technology investments. However, the long-term access and usage conditions of the e-records have not been planned. In this study, the need for a strategy that includes viable solutions at the national and institutional levels regarding the future of digital documents is discussed. For the study, we used the qualitative research method and reviewed the available literature with due diligence. The data obtained from the literature review were evaluated using the document analysis technique. Despite the policy development efforts within the scope of the information security standard, the subject of the present study is about document security beyond information. Otherwise, 
irreparable risks await us, such as the destruction of information assets that are in the form of documents. Although interoperability principles and standards have been published, these are not enough for organizations to produce sustainable policies on the preservation of the integrity of electronic records, long-term preservation of e-signature, digital sustainability, transfer of e-records, and their storage in archives. Authorized institutions related to the field should develop strategies for the sustainability of e-records.

Keywords: Electronic records management, e-Archive records, e-Records strategy, Digital archives

\section{EXTENDED ABSTRACT}

Different studies show that electronic records management system (ERMS) applications in institutions contain potential risks as well as opportunities. One such risk is regarding the long-term sustainability of e-records. There is a need for a road map where these and similar possible threats can be eliminated, followed by correct predictions and solutions. To achieve this, organizations should create strategies to ensure electronic sustainability after recognizing potential risks and opportunities. Ensuring the electronic continuity of e-records that need to be stored for a long-term access without breaking the escrow/ownership chain, and without destroying their integrity and reliability, can be possible by making short- and long-term plans.

This research handles the sustainability problem of e-records with a qualitative approach. Therefore, our research not only describes problems but also suggests what are the roots of the problems and their possible solutions. Within the scope of this study, resources were examined and document analysis techniques were used to obtain qualitative data. While evaluating the data, legal and administrative procedures were analyzed along with the literature.

The increasing everyday use of information technology products in realizing the business processes of institutions creates problems related to the production, use, preservation, and long-term accessibility of e-records. For example, although these e-records, which are an output of ERMSs in institutions, are evident in the market in terms of form, format, and carrier media, it is not known what kind of technical solutions they will require in the long-term. At the same time, necessities in technological migration are not taken under much consideration. There are general explanations about the subject in the field of informatics. However, specific requirements regarding the long-term preservation of digital records under the conditions in Turkey need further understanding. For example, the interoperability principles issued by the Ministry of Development State that e-records should be in PDF/A format, especially for longterm storage. However, for archived e-records, it is essential to protect their authenticity and integrity. Therefore, determining the format alone does not constitute a solution for possible problems. Broader criteria should be explained, and these should guide the development of strategies.

Although different countries set their own standards to overcome the abovementioned difficulties, conditions vary among countries. Therefore, translating the procedures of other 
nations into Turkish and putting them into use does not seem like a solution-oriented approach. System infrastructures, document formats, and technological needs developed according to the conditions of Turkey should be taken into consideration. The solutions disclosed for the current use of the records are not sufficient for the period in which they were archived. In other words, standards that aim to change management for the success of ERMS applications can be a guide for e-records in the current period. However, such procedures are not sufficient to answer questions on how to preserve the originality of the older archived e-records. Theoretical and academic research is being undertaken to study the long-term threats faced by Turkey. However, no roadmap has been drawn to eliminate this threat. National strategies are needed to ensure that the authenticity and integrity of archived e-records is maintained over a long period without deterioration.

Institutions should address the technological migration issue of their original and authentic e-documents as soon as possible. Thus, a road map is needed to be drawn to ensure the sustainability of e-records. Examples of such road maps are found in countries such as Australia and England. Turkey has an urgent need for a similar study. The administrative departments that are in the position of authority in the field of e-governmenance, e-information, and e-records, such as the Information Society Department under the Presidency of Strategy and Budget and the Presidency of State Archives, have an important role in building the road map. Countrylevel strategies can be a model for institutions. According to these strategies, organizations can create their own road maps. 


\section{GíRiş}

Organizasyonlar, iş süreçlerini daha hızlı, verimli ve şeffaf yönetebilmek için elektronik belge yönetimi sistemi kurmaktadır. Bu sistemlerde dokümanlar, belgeler, e-postalar, kelime işlemci dosyaları, fotoğraf ve resimler, veri tabanları, çizelgeler tek bir dosya ya da bütünleşik dosya şeklinde üretilip kullanılmaktadır. Her gün idari işlemlerin artmasına bağlı olarak hızla çoğalan bu belgelerin güvenilir şekilde üretilmelerinin yanı sıra uzun vadede tekrar erişilip kullanılabilecek şekilde tutulmaları gerekmektedir. Ancak, bu belgelerin uzun süre korunup, erişimde devamlılıklarının sağlanmasıyla ilgili olarak ortaya çıkan soru işaretleri Türkiye'de henüz yeterli cevabı bulmuş değildir. Günümüzde elektronik belge yönetimi sistemlerinin (EBYS) çıktısı olan e-belgelere uzun vadede erişememek, erişilse dahi ilk üretildiğindeki özgünlüklerini koruyamamak riski, ciddi bir tehdit olarak çözümlenmeyi beklemektedir.

Bu tür risk ve tehditlerin değerlendirildiği konuları sınırlı da olsa bazı çalışmalarda görüyoruz. Türkiye'deki üniversiteler üzerine yürütülen bir projenin sonuç raporunda, elektronik ortamda üretilen dokümanların tamamında e-imza kullanılmadığı ve özgünlüğün korunabilmesi için mutlaka e-imza altyapılarının tamamlanması gerektiği, üniversitelerin yarıdan fazlasında belge ve arşiv hizmetlerine yönelik bir yönetmeliğin olmadığı, çoğunda dosya planının düzenli kullanılmadığı, yarıya yakınında da saklama planı bulunmadığına işaret edilmiştir. Elektronik sistemlere dönük yaşanan sorunlar ise aranan bilgiye erişim problemleri, içeriğin uzun süre saklanmasında özniteliklerinin korunamaması sorunu, belgenin bütünlüğü ve özgünlüğünün bozulması riski, güvenlik tehditleri ve yedekleme olanaklarının yetersizliği olarak belirlenmiştir (Külcü, Çakmak ve Özel, 2015, s. 249). Üretildiği ve kullanıldığı örgüte özgü ve özgün olduğu düşünülen bu kurumsal belgelerin kaybı, telafisi mümkün olmayan idari, hukuki ve maddi sonuçlar doğurabilir.

Henüz tam cevap bulunamamış bu risk ve tehditlere rağmen Türkiye'de genelde bilgi teknolojisi ve bilişim, özelde ise kayıtlı bilgi varlıklarıyla ilgili olarak EBYS kurmak, dijitalleştirme yapmak ve elektronik arşiv oluşturmak gibi yatırımlar yadsınamayacak kadar fazladır. Kalkınma Bakanlığının yayınlamış olduğu Kamu Bilgi ve İletişim Teknolojileri Yatırımları adlı dokümanda bildirildiğine göre "2002 yılında merkezi yönetim bütçesinden 203 adet BİT (Bilgi ve İletişim Teknolojileri) yatırım projesi için tahsis edilen ödenek yaklaşık 694 milyon TL iken, geçen 12 yıllık süre içerisinde 5 kattan fazla bir artış kaydeden kamu BİT yatırımlarına 2014 yılında 263 proje için 3 milyar 684 milyon TL ödenek tahsis edilmiştir” (2014, s. 1-2). 2020 yılında ise bu rakam kısmen artırılsa da çok fazla değişmemiş, 281 proje için 3 milyar 713 milyon TL ödenek ayrılmıştır (Kamu Bilgi ve İletişim Teknolojileri Yatırımları Raporu, 2020, s.1). Bu ödenekler içerisinde Çevre ve Şehircilik Bakanlığının "Elektronik Doküman Yönetimi Sistemi Yaygınlaştırma Projesi, yine aynı Bakanlığın Fiziksel ve Dijital Arşiv Düzenleme ve Dijital Arşiv Yönetimi Sistemi Uygulaması adıyla farklı projelere 4 milyon TL, Dışişleri Bakanlığının Arşiv Düzenleme ve Sayısallaştırma işi adıyla 30 milyon 
TL, Ekonomi Bakanlığının EBYS için 1 milyon 790 bin TL ayırdığı görülmektedir (Kamu Bilgi ve İletişim Teknolojileri Yatırımları, 2014, s. [13-14]). Yine örnek olması için 2020 yılı raporunda AFAD'ın Belge Yönetimi ve Elektronik İmza Sistemlerinin Kurulması Projesi için 1 milyon 575 bin TL, Sosyal Güvenlik Kurumu (SGK) 2010 yılında başlayan ve bitişi 2022 olarak planlanan E-İmza ve Mobil İmza Destekli E-Belge ve Arşiv Yönetimi Sistemi Kurulması ve Yaygınlaştırılması projesi için tahsis edilen toplam rakam 194.060.000 TL.dir (Kamu Bilgi ve İletişim Teknolojileri Yatırımları Raporu, 2020, s.12). Kaldı ki bu raporlarda yerel yönetimlerin yatırımları yer almamaktadır. Tüm bu yatırımlar göz önünde bulundurulursa kurumsal bilgi ve belgelerin yönetimiyle alakalı ciddi kaynak ayrıldığı söylenebilir. Bu kadar maddi kaynak ayrılmasına rağmen, yatırımların geri dönüşü bağlamında projelerin uzun süreli kullanım ve devamlılığıyla ilgili olarak elle tutulur ulusal ölçekte bir stratejinin bulunmaması oldukça manidardır.

Bu yatırımlar neticesinde kurumsal bilgi kaynakları hızla sayısallaştırılmakta, belge hacmi ise katlanarak büyümektedir. İstanbul'daki ilçe belediyeleri arasında EBYS'sini olması gereken sistem kriterlerine göre kurup işleten öncülerden biri olan ve TS 13298 Kurumsal Sertifikayı ilk alan Bağcılar Belediyesinde üretilen elektronik bilgi ve belgelerin 2017 yılı itibariyle günlük, aylık ve yıllık hacimleri oldukça dikkat çekicidir. Belediyenin Bilgi Yönetimi Sistemindeki bilgi ve belge boyutu şu şekilde ifade edilmiştir. Kurumda içerik yönetimi yapılabilen dijital arşivdeki belge boyutu 1 TB (Terabyte); yönetim bilgi sistemindeki veri boyutu ise $810 \mathrm{~GB}$ (Gigabyte) olup, toplamda 1.8 TB'lik bir hacme karşılık gelmektedir. Belediyedeki elektronik ortamda tutulan belge sayısı yaklaşık 5 milyon adettir. Bunların 1,5 milyonu e-imzalı olup, tarama yapılarak dijitalleştirilen belge sayısı, 3,5 milyondur (Yılmaz, 2017). Tüm bunların büyüme hızları da dikkat çekicidir. Kurumdaki günlük veri büyüme miktarı $800 \mathrm{MB}$, aylık ortalama 23,4 GB, yıllık ise 285 GB'lık bir hacme karşılık gelmektedir (Yılmaz, 2017). Elektronik bilgi ve belge hacmi, onların üretilme durumuna, saklanma koşullarına ve formatına göre de farklılık gösterebilmektedir.1

Tüm kurumlarda hızla büyüyen dijital belge hacmi karşısında, ilerleyen yıllarda özniteliklerinin korunmasına yönelik bir plan ya da programın varlığı sorgulanmaktadır. Çünkü katlanarak büyüyen ve her biri hukuki delil niteliğinde olan e-belgelerin ilk üretildiği orijinal hâliyle erişilebilir olması gerekir. Ancak ülkede bu konuda gözle görülür bir prosedüre henüz rastlanamamaktadır. Her ne kadar 27001 numaralı Bilgi Güvenliği Standardı mevcut olsa da Standardın sistem kriterlerinin usulüne uygun işletilerek uygulanıp tatmin edici sonuçlar beklemek yanıltıcı olabilir (Sağlık Bakanlığı Bilgi Güvenliği Politikaları Kılavuzu, 2019). Çünkü bu yazıda tartışılan konu, bir siber saldırıya maruz kalınması durumunda bilgi için güvenlik

1 Örneğin mevcut kâğıt ortamdaki belgelerin dijitalleştirilmesi ile ortaya çıkan hacim ile doğrudan e-imzalı olarak üretilip mesela bir PDF/A olarak saklanan belgelerin hacmi aynı değildir. TIFF (Tagged Image File Forma), JPEG (Joint Photographic Experts Group) veya PDF (Portable Document Format), formatında dijitalleştirilmiş belgelerin hacminin daha fazla yer tuttuğu bilinmektedir (Yılmaz, 2017). 
risklerini en aza indirmek meselesi değildir. Asıl olan bilginin taşındığı belgelerin üstverisinin nasıl korunacağının, e-imza algoritmasının nasıl güncelleneceğinin, belge bütünlügüunün nasıl muhafaza edileceğinin güvenli bir yapıya kavuşturulmasıdır. Konuya belge perspektifinden bakan strateji ve eylem planlarına ihtiyaç vardır.

Bu makalede Türkiye'deki kamu idaresinde var olan elektronik belgelerin uzun vadede erişilebilirlikleriyle alakalı olarak bekleyen riskleri en aza indirmenin yolları tartışılmaktadır. Çalışmanın esas amacı, e-belgelerin devamlılığını sağlayabilmek için bir stratejiye ihtiyaç olduğunu göstermektir. Çünkü EBYS' de yaşanan problemler, -çözüm üretilmemesi halindeyakın gelecekte ciddi risk ve tehdit oluşturma potansiyeline sahiptir.

Farklı ülkeler, ileriki yıllarda ortaya çıkabilecek muhtemel tehditlerin önüne geçmek için önlem almaya çalışmaktadırlar. Bunların bir kısmı politika belirlemek, bazıları karar almak ve planlar geliştirmek şeklindedir. Örneğin Avustralya ve Yeni Zelanda'nın elektronik arşiv belgelerinin ve belge sistemlerinin kalıcılıklarını daha güçlü kılmak için oluşturdukları stratejilerden açık kaynak kodlu sistemleri teşvik ettikleri görülmektedir. Açık kaynak kodlu sistemler hem ticari yazılımların oluşturabileceği tekelin önünü kesecek hem de gelecekte yaşanabilecek teknolojik sorunlar için daha geniş bir çözüm ortamı oluşturacaktır (Digital Continuity Action Plan, 2009).

Kurumların, EBYS uygulamalarında firsatlar kadar potansiyel riskleri de barındırdıklarını yapılan çalışmalardan öğrenmekteyiz (Yalçınkaya, 2016, s. 77). Bunlardan biri, "Üretilen e-belgeler, sürdürülebilirliği olan sistemlerde yönetilebiliyor mu?” sorusudur. Bunun için özellikle yönetmelik, genelge ve standart gibi prosedürlerle belirlenmiş EBYS uygulama kurallarının ne kadarının gerçek hayata yansıtıldı ğı; yansıtıldı ise ne ölçüde başarıldığı; başarılamıyorsa sebeplerinin neler olduğu, ölçülebilir veriler ışığında görülebilmelidir. Potansiyel tehditlerin doğru öngörülerle olgunlaştırılıp çözüm planlarının takip edileceği bir yol haritasına ihtiyaç bulunmaktadır. Bunun için kurumlar mevcut durum tespiti yapıp potansiyellerini ortaya çıkardıktan sonra elektronik devamlılığı sağlayacak eylem planı hazırlamalıdır. Uzun süreli saklanması gereken e-belgelerin emanet/mülkiyet zinciri koparılmadan, bütünlüğü bozulmadan, güvenilirliğini yok etmeden sürdürülebilirliğini sağlamak, kısa ve uzun vadeli planlar yapmakla mümkün olur (Isa, 2011).

\section{Kavramsal Çerçeve}

Her geçen gün kurumların iş süreçlerini gerçekleştirmede bilgi teknolojisi ürünlerin daha çok kullanılması e-belgelerin üretim, kullanım, muhafaza ve uzun süre erişilebilirliğiyle ilgili problemleri de beraberinde getirmektedir. Örneğin kurumlardaki elektronik belge yönetimi sistemlerinin bir çıktısı olan bu e-kayıtların ticari olarak piyasadaki isimleri bilinse de form, format ve taşıyıcı ortam itibariyle lisanlı veya lisanssız olarak örgütlerde ne tür örneklerin 
bulunduğu, çeşitlilikleri, teknik özellikleri, teknolojik göç ettirmede gereksinimleri, bunun için uzun vadeli stratejiler konusu cevap bekleyen sorular barındırmaktadır.

Bilgi teknolojileriyle alakalı her ne kadar geneli kapsayan açıklamalar olsa da özellikle e-belgelerin uzun süre korunmasıyla ilgili müstakil planlara ihtiyaç duyulmaktadır. Örneğin Kalkınma Bakanlığının çıkarmış olduğu Birlikte Çalışabilirlik Esasları, e-belgelerin özellikle uzun süre saklanma durumu için PDF/A formatında olması gerektiğini belirtmektedir (Birlikte Çalışabilirlik Esasları, 2012). Oysa arşiv malzemesi olmuş elektronik belgeler için gerçekliğin ve bütünlüğün korunması esastır. Dolayısıyla sadece format önerisinde bulunmak olası problemler için çözüm teşkil etmemektedir. Daha kapsamlı kriterler açıklanmalı, bunlar da geliştirilecek stratejilere yol göstermelidir.

Farklı ülkelerde, o ülke şartları ve buna bağlı ihtiyaçlar göz önünde bulundurularak, teknolojik devamlılıkla ilgili stratejik çalışmalar yapıldığı bilinmektedir (Xie SL, 2012). Buralardan elde edilecek sonuçlar Türkiye'yi yansıtmasa da araştırma yöntemi olarak kullanılabilir. E-belgelerin erişiminde devamlılığın sağlanmasıyla alakalı planlar yapabilmek için ülke gerçeklerinin açığa çıkarılması gerekmektedir. Dijital süreklilik konusunda yürütülecek bir saha araştırması, problemlerin tespitine ve çözümüne yönelik gereksinimlerin anlaşılmasına yardımcı olacaktır. Fakat bu konuyla alakalı mevcut prosedürler üzerine hazırlanmış olan bir yayın (Özdemir ve Cengiz, 2019, s. 292) yapılacak bir saha çalışmasında karşılaşılacak muhtemel sonuçların ipuçlarını göstermektedir. Ne yazık ki mevcut prosedürler ülkede bu konunun çok da bilincine varılmadığına işaret etmektedir. Hâlbuki bu durum zaman içerisinde elektronik bilgilerin okunamaması ya da gerektiğinde bulunamamasına sebep olarak bilgi kaybına yol açabilir (2019, s. 292). Çünkü özellikle çok hızlı değişen ve gelişen bilgi teknolojisi ve ona dayalı ürünler, belge yöneticileri ve arşivcilerin kontrolü dışında hayatımıza girmektedir. Hızlı gelişmenin doğal sonucu olarak bilginin üretim, dolaşım ve muhafaza koşulları da değişmektedir. Bu sebeple e-belgelerin sürekli erişilebilirliğini sağlamak için değişsen koşulların çok iyi değerlendirilmesi gerekmektedir.

\section{2. Çalışmanın Amacı, Kapsamı ve Yöntem}

E-belgelerin uzun süreli korunmalarıyla alakalı olarak ne tür hareket tarzı belirlenmesi gerektiği konusunda yol haritası çok belirgin değildir. TS 13298 Elektronik Belge ve Arşiv Yönetimi Standardı (2015) gibi prosedürler olsa da sahada karşılaşılan örneklerde, bu Standardın sistem kriterlerinin çok da karşılanmadığı görülmektedir. Makalenin başlıca amacı Türkiye'deki kamu idaresinde var olan elektronik belgelerle ilgili -devlet politikası olarak- geliştirilmesi gereken strateji gereksinimi olduğunu açığa çıkarmaktır.

Her ne kadar sektör ve kurum düzeyinde yapılan çalışmalar kanaat oluşturacak bir fikir verse de Türkiye genelinde EBYS uygulama yazılımlarının ürettiği e-belgelerin durumuyla 
ilgili sağlıklı bilgiye çok da sahip değiliz. Kurumlardaki uygulamalar sonrası ortaya çıkan elektronik belge, doküman ve klasörlerin belge yönetimi ve arşivcilik normlarına ne kadar uygun üretilip saklandıklarını tam bilemiyoruz. Sertifika (TS 13298) almakla teorik olarak belge yönetiminin tüm fonksiyonlarının yürütülebildiği düşünülen yazılımların, gerçek senaryolardaki performansları yeteri kadar değerlendirilmiş değildir. Sertifika almış olanların operasyonel işlerdeki gücü, ölçülmeyi beklemektedir (Özdemirci ve Alyakut, 2012, s. 558). Yurt dişında yapılan bir araştırma sonuçlarına göre elektronik belge yönetimi gibi bilgi sistemleri üzerine geliştirilen projeler yüksek oranda başarısızlıkla sonuçlanmaktadır. Büyük ölçekli EBYS projelerinde bu oranın \%50 ile \%80 arasında olduğu ifade edilmektedir (Dorsey, 2005). Her ne kadar yurt dışında önceden yapılmış bir araştırma olsa da bir ipucu vermesi bakımından, sonuçları dikkatlice analiz edilmeye değerdir. Bu durumun Türkiye' de hangi düzeyde olduğu tahmin edilmekle birlikte, rakamlara dayalı olarak şimdilik bilinememektedir.

Belge yaşam döngüsünde, üretimden tasfiyeye ve hatta arşiv yönetimine kadar birçok iş süreci bulunmaktadır. Bu adımlar, belge üretimi, bütünlüğün sağlanması, kayıt, sisteme dâhil etmek, e-imza, dağıtım, kayıtlı elektronik posta, dosyalama işlemleri, saklama, tasfiye ve arşivleme şeklindeki fonksiyonlardır. Bunların her biri ayrı ayrı değerlendirilebilir. Burada belgelerin arşivlenme sürecinde uzun süre saklanmalarıyla alakalı strateji geliştirmek konusu ele alındığından kapsamı da belirtilen fonksiyonlardan ağırlıklı olarak arşiv safhası ile sınırlandırılmıştır. Arşıvlenen elektronik belgelerin uzun sureli kullanılabilirliği için kurumların hareket tarzı incelenecektir. Burada amaç, e-belgelerin muhafaza edilme sürecinde orijinalliğinin bozulmaması için alınması gereken tedbirlerle ilgi olarak kurumların strateji gereksinimlerini açıklayabilmektir. Çalışma bahsedilen teorik kapsam bağlamında sınırlandırılsa da adı geçen döngüdeki fonksiyonların işlerliği de doğal olarak bu makaleyi ilgilendirmektedir. Örneğin EBYS'nin üretilen e-belgelerin özgünlüğünü sağlayıp sağlamadığı, sağlıyorsa nasıl yaptığı önemli bir veridir. Fakat elektronik belge bütünlüğünün ne olduğu, otantikliğin anlamı ve sağlanma koşulları, yine belgelerin form özellikleri gibi bilgiler bu makalede doğrudan ve detaylı olarak ele alınacak konular arasında değildir. Aynı şekilde sistem içerisinde dosyalamanın nasıl işlediği bir sonuçtur. Ancak, bunu sağlayan dosya planının nasıl geliştirildiği, kodlama mantığı veya ana ve alt konu başlıklarının yapısını değerlendirmek de yine bu yazının kapsamı dışındadır.

Makalenin teorik kapsamı dâhilinde olan konulardan biri, elektronik belgelerin devamlılı̆̆1 ve arşivlenme sürecinde özgünlügün nasıl korunacağı durumudur. Bu konuyla ilgili olarak hem Türkiye'de hem de dünyadaki gelişmeler ışığında yapılan çalışmalar değerlendirilmiştir. Mevcut bibliyografya, veritabanları ve e-kaynaklar incelendiğinde ülkelerin milli arşivleri başta olmak üzere ICA (Uluslararası Arşiv Konseyi) gibi örgütler ile üniversiteler tarafından e-belgelerin sürdürülebilirliği ile ilgili çeşitli çalışmalar yapıldığı görülmüştür. Bunların bir kısmı makalenin literatür alanında takdim edilmiştir. Bu kaynaklar incelenerek e-belgelerin otantikliğini ve devamlılığını sağlamanın ne anlama geldiği, nasıl sağlanabildiği, koşullarının 
ne olduğuyla ilgili olarak farklı ülkelerde yapılan çalışmalar görülmeye çalışılmıştır. Benzer çalışmaların Türkiye için de ivedilikle yapılması gerektiği değerlendirilmiştir.

Makale niteliksel bir araştırmadır. Bundan dolayı araştırma, sadece sorunları tanımlayıcıbetimleyici değil, aynı zamanda sorunların nedenleri, muhtemel çözüm yolları üzerine de düşünce ortaya koyan bir özellik taşımaktadır. Çalışma kapsamında nitel verilerin elde edilmesinde kaynaklar incelenmiş ve belge analiz teknikleri kullanılmıştır. Nitel verilerin toplanmasında literatür ile birlikte yasal ve idari prosedürlerin analizi yapılmıştır.

\section{E-Belgelerin Geleceği İçin Literatüre Dayalı Öngörüler}

Literatür incelemesi sırasında konuyla doğrudan ve dolaylı ilişkisi bulunan araştırmalara rastlanmıştır. Burada ilk olarak doğrudan konuyla ilişsisi olanlar değerlendirilmiş; ardından, elektronik bilgi ve belgelerin devamlılığının sağlanması, elektronik belge yönetimi sahasında yaşanan güçlükler, e-belgelerin otantikliği ve güvenilirliği üzerine yapılan çalışmalar ele alınmıştır.

Türkiye'de çıkmış olup makalenin inceleme konusuyla ilgili bir iki çalışma mevcuttur. Bunlardan ilk ikisi, Kandur’un makalesi ile Külcü başkanlığında yürütülen bir TÜBİTAK projesidir. Kandur, Bilgi Dünyası dergisinde yayınlanan "Türkiye'de Kamu Kurumlarında Elektronik Belge Yönetimi: Mevcut Durum Analizi ve Farkındalığın Artırılması Çalışmaları” adlı makalesinde, 2009 yıl itibariyle kurumlarda \%19 oranında tamamen, \%47 civarı da kismen EBYS'ye geçildiğini belirtmektedir (Kandur, 2011, s. 6-11). Çalışmada kurumların e-belgenin arşivlenmesi ve devamlılığıyla ilgili bir stratejilerinin olup olmadığını açıkca öğrenemesek de e-belge kullanım ve paylaşım oranları bu makale için kayda değer verilerdir. Oysa örgütlerde belge yönetimi politikalasının bulunması (Çiçek, 2020, 377-405), stratejik plan yapabilmek için önemli bir alt yapı sağlayacaktır.

Külcü ve arkadaşlarının 2014 yılında TÜBİTAK projesi olarak tamamlayıp 2015'de kitaplaştırarak yayınladıkları IntePARES 3 Kurumsal Bilgi Sistemleri İçerisinde Belge Yönetimi: Türkiye'deki Kamu Üniversitelerinde Gerçekleştirilen Uygulamalara Yönelik Bir Durum Analizi adlı çalışmada yukarıda sözü edilen birçok çekincenin yerinde tespit edildiği görülmüştür. Yirmi iki devlet üniversitesi incelenmiş ve bunlara ait elektronik belge yönetimi programlarının geliştirilmesi için çok yönlü araştırmaların yapılmasının gerektiği belirtilmiştir. Bunun ilkini geliştirilen standartlar, düzenlemeler ve uygulama örneklerinin incelenmesi oluşturmakta olup, bu aynı zamanda program geliştirme faaliyetlerinin de ilk aşamasıdır. Kurumların yönetim yapıları, teşkilat şemaları, birimleri ile bunların yürüttüğü fonksiyonların değerlendirilmesi gerektiği açıklanmıştır. Daha sonra EBYS'lerle ilgili sorunlar açığa çıkarılarak, uzman kişilerin görüşüne başvurulması gerektiği belirtilmiştir. İlginç sonuçların elde edildiği projede bazı yerlerde elektronik ortamda üretilen belgeler için e-imza kullanılmadığı belirtilmiştir. Üniversitelerin 
yarıdan fazlasında belge ve arşiv hizmetleri için yönetmelik gibi bir prosedürün bulunmadığ tespit edilmiştir. Dosya planlarının düzenli kullanılmadığı; hatta, çoğunda saklama planı bulunmadığı açıklanmıştır. Sisteme dönük sonuçlar ise aranan bilgiye erişim sağlama, içeriğin uzun süre korunması, bilginin bütünlüğü ve özgünlüğünün korunması, güvenlik tehditleri ve yedekleme olanaklarının yetersizliği şeklinde açıklanmıştır (Külcü, Çakmak ve Özel, 2015).

Makalenin tartıştığı konuyla ilgili olarak farklı ülkelerde yapılan akademik ve teknik çalışmaların yoğunluğu, yakın gelecekte bu konunun ne ölçüde önemli olduğuna işaret etmektedir. Her ne kadar makale kurumsal belgelerle sınırlı olsa da insan düşüncesi bilginin kayıtlı olduğu bütün elektronik ortamlar için uzun süreli koruma ve erişimde devamlılık temel tartışmalardan biridir (Digital Preservationa Coalition, 2021). Birçok uzmana göre dünya kültür mirasının savaş, yangın ve doğal afet gibi tehditler karşısında yok olmasını önlemek için elektronik ortama taşınması kaçınılmazdır (Tonta, 2009). Fakat iyi niyetli bu gayretler sonucu elde edilen taşıyıcıların uzun süreli erişilebilirliği ile ilgili riskler henüz atlatılmış değildir. Uluslararası meslek örgütleri konuyla ilgili duyarlılığı artırmak adına çeşitli eğitim dokümanları üretmişlerdir (Digital Preservation in Lower, 2016). Dolayısıyla risk ve tehditler sadece kurumsal belgeler için değil, e-bilginin bulunduğu bütün taşıyıcılar için geçerlidir. Bu tehditler artarak devam etmektedir. Örneğin Ataman'ın 2005 (s. 78-100) yılında çıkan yazısında öngördüğü çoğu problem hâlâ varlığını korumaktadır. Ataman, "Elektronik Ortamdaki Bilginin Arşivlenmesi" adlı makalesinde elektronik belgelerin uzun süre saklanmasıyla alakalı olarak var olan riskleri, ilk olarak taşı1ıı ortam ve sürücüler olarak belirlemiş, daha sonrakileri ise donanım, işletim sistemi ve uyguma programlarındaki sorunlar şeklinde açıklamıştır. Belgelerin uzun süreli saklanmaları konusuna, proje ve yayınların yanı sıra kurumlar düzeyindeki çalışmalarda da rastliyoruz. Erik A. M. Borglund ve Karen Anderson'un (2011, s. 271-282) birlikte sunduklar1 bir tebliğde güncel belge yönetimi ile ileride erişilebilirliği sağlamak için muhafaza ilişkisini ele almışlardır. Bunu yaparken daha çok erişilebilirliğe engel olabilecek güçlüklerin neler olduğunu, bunların nasıl en aza indirilebileceğini tartışmışlardır. Bir kurumdaki vaka çalışması üzerinden ele aldıkları erişilebilirlik konusuna stratejik öneriler getirmişlerdir. Bu konuda uzak doğu ülkelerinde de çeşitli çabaların olduğunu yayımlanan makalelerden öğreniyoruz. Çin Renmin Üniversitesinden Yuenan (Linda) Liu, Çin'de e-belgelerin arşivsel değerinin korunmasıyla ilgili olarak çeşitli üniversite ve araştırma merkezlerinde projeler yürütülüyor olmasına rağmen, tartışmaların hâlâ bitmemiş olduğunu, çünkü alanda boşluklar bulunduğunu dile getirmektedir. Liu, makalesinde ayrıca e-belgelerin uzun süre korunmasıyla alakalı olarak milli stratejiler gerektiğini belirtmektedir (2014, s. 213-222).

E-belge üreten sistemler üzerine de çokça inceleme bulunmaktadır. Mesela bunlar arasında Amerika Milli Arşiv ve Belge Yönetimi Bürosunun 2000'li yıllarda kurumlardaki elektronik belge ve doküman yönetimi sistemleriyle ilgili giriştiği projelerdir. Bu projelerin, e-belgelerle alakalı farklı problemlerle yüzleşmeye başlamanın sonucunda geliştiğini görüyoruz. Projelerin 
sonuçlarını değerlendiren bir takım yayınlara da rastlıyoruz. Giovanna Patterson ve J. Timoty Sprehe'in birlikte kaleme aldıkları "Principal challenges faceing electronic records management in federal agencies today" adlı makalede (2002, 307-315), Amerika'daki federal bürolarda elektronik belge yönetimiyle ilgili karşılaşılan güçlükler değerlendirilmiştir. Çalışmada e-postaların yönetiminde yaşanan problemler, bilgi teknolojisi bileşenlerinin sistem dizaynı ve mimarisinde doğru planlamanın yapılamaması, geleneksel belge yönetimi anlayışının yenilenmesinde zorluklarla karşılaşılması ve özellikle bu anlayışla elektronik belge yönetimi sistemlerinin örtüştürülmesinde, aynı zamanda bu sistemin örgütlerdeki diğer bilgi yönetimi sistemleriyle entegrasyonunda yaşanan güçlükler dile getirilmiştir.

Zaman içerisinde buna benzer güçlüklerin Türkiye' deki kurumlarda da görüldüğünü yine yayınlanan çalışmalardan öğreniyoruz. Külcü ve Umut, ortaklaşa hazırladıkları "Elektronik belge yönetimi uygulamalarında karşılaşılan sorunların analizi ve çözüm önerileri: Kalkınma Bakanlığı örneği” adlı makalede (2014, s. 102-124), e-devlet uygulamaları kapsamında geliştirilen EBYS'lerden bir örnek olarak Kalkınma Bakanlığındaki sistemi analiz etmeye çalışmışlardır. Makalede Bakanlığın Ankara merkez teşkilatında bulunan ve sistemi kullanma yetkisi olan 804 kişiye anket uygulanarak onların gözünden sistemde aksayan yönler ve çıkan sorunlar belirlenmiştir. Çalışma bir kuruma dönüktür. Çalışanların görüşleri üzerinden problemler tespit edilmiştir. Her ne kadar yazıdan faydalanılacak bilgiler bulunsa da bir kurum üzerinde çalışıldı̆̆ 1 için geneli yansıtmamaktadır.

Kaynaklar arasında e-belgelerin idari, hukuki ve diplomatik açıdan güvenilirlik tehditlerini inceleyen eserler de yadsınamayacak kadar önemlidir. Elektronik ortamda bulunan belgeler bir kâğıt ya da mikroform niteliğindeki belgelere göre daha hassastır. Doğal ve fiziksel şartlardan ve manyetik etki alanlarından çok kolay etkilenebilirler. Bu yapıları nedeniyle uygun biçimde yönetilmezlerse basılı ortamdan çok daha ciddi sorunlarla karşılaşılması söz konusu olabilir. British Columbia Üniversitesinde (Kanada) öğretim üyesi olan Luciana Duranti’nin yöneticiliğini yaptığı birçok proje bu konuya ilişkin farklı çözüm önerileri getirmiştir. E-belgelerin diplomatik özelikleri üzerine tartışmaların olduğu bu projelerde e-belgelerin orijinalliğini ve güvenilirliğini uzun süre sağlamak adına stratejik öneriler sunmaktadır. Proje raporlarından birinde 1960'larda manyetik teyplerin kullanılmasından bu yana 1000'in üzerinde farklı dijital formatın kullanıldığı, bunların kullanım sürelerinin 10 yılı geçmediği ve her iki yılda bir yeni bir formatın kullanılmaya başlandığına işaret edilmektedir (InterPARES, 2002).

Örgütlerde belgeler elektronik ortamda yönetilmeye çalışılırken önceden belirlenmiş sistem kriterlerine uyulması, e-belgelerin otantikliğini uzun sure korumak adına öngörüde bulunmayı kolaylaştırmaktadır. Çünkü kriterlerin uygulandığı sistemlerde üretilmiş e-belgeler için e-imza varlığının korunması, orijinalliğinin bozulmaması ve delil değerinin muhafazasıyla alakalı olarak yapılanların bilinmesi, ilerisi için strateji belirlemeyi kolaylaştırabilir. En azından yapılanlardan haberdar olmak, bundan sonrası için ne tür önlemler alınabileceği hakkında yol gösterecektir. 
Bu konuda 2015 yılında güncellenen TS 13298 Standardı önemli bir referanstır. Bu Standart' $1 n$, özellikle 2008 yılından itibaren uygulama yazılımlarında başlıca kaynak olması gerektiği açıklanınca (Genelge, 2008), söz konusu Standarda yönelik ilgi biraz daha artırmıştır. Yılmaz 2012'de yayınladığı makalesinde Standart'ta açıklanan kriterleri değerlendirmiştir. Eroğlu ve Külcü ise 2014'de (2014, s. 327-352) yayınladıkları “TS 13298 çerçevesinde kurumsal bilgi sistemleri ve elektronik belge yönetimi standartlarının değerlendirilmesi: İçişleri Bakanlığı örneği” başlıklı makalede adı geçen Bakanlıktaki EBYS uygulamasında Standart’ta öngörülen koşulların karşılanıp karşılanmadığını incelemişlerdir. Daha önce de belirtildiği gibi çalışma her ne kadar bir inceleme modeli sunsa da bir kurumla sınırlı kaldığg için Türkiye'nin tamamını yansıtmamaktadır. Bundan dolayı makalenin sonuçlarını ülke için genelleyemiyoruz.

Literatür taranırken göz önünde bulundurulan önemli bir husus, "e-belgelerin yönetilmesinde sürdürülebilirlik" konusunu ve buna ilişkin "strateji” temasını işleyip işlemediklerine bakmak olmuştur. Bu makalenin ortaya çıkışında temel gerekçelerden biri, "Yakın gelecekte, bugün üretilen e-belgelere erişebilecek miyiz?” aynı şekilde, "Bunları üretildikleri özgünlükte bulabilecek miyiz?” sorularıdır. Bunun için milli arşiv benzeri kurumlar ne tür stratejiler geliştirmeli ve bunun için gerekli veriler nereden elde edilebilir. Odabaş’ın (2010) belirttiği gibi kurumların farklı formatta üretip yine farklı taşıyıcı ortamda tuttuğu e-belgelere teknolojik göç yaptırılmazsa gelecekte onu kullanamama riski oldukça yüksektir. Dolayısıyla örgütlerde güncel belgelerin kontrolüne yön verecek, aynı zamanda milli arşive düzenli belge ve dosya akışının alt yapısını oluşturacak elektronik belge stratejilerine ihtiyaç bulunmaktadır (Arısoy ve Özdemirci, 2017, s. 1251-52). Bu tarz stratejiler e-belgelerin devamlığını sağlamaya yönelik önemli argümanlardır. Bunlar oluşturulmadığı sürece gelecekte kaçınılmaz riskler bulunduğu dile getirilen e-belgeler için “dijital süreklilik” öncelikli konular arasında olmaya devam edecektir.

Özdemir ve Cengiz'in birlikte kaleme aldıkları yazılarında (2019, s. 273) Türkiye'de dijital sürekliliğin tam anlaşılamadığını değerlendirmişlerdir. E-belgelerin geleceğiyle ilgili olarak Bilgi Edinme Hakkı Kanunu'ndan E-İmza Kanunu'na kadar daha birçok prosedürü inceleyerek, buralarda dijital sürekliliğe yeteri kadar yer verilmediğini ortaya koymuşlardır.

Konuyla ilgili olarak yurt dışında çeşitli çalışmalar yapıldığını görüyoruz. Avustralya, Yeni Zellanda ve (Digital Continuity 2020 Policy, 2015) İngiltere gibi birçok ülkede politikalar ve strateji belgeleri bulunmaktadır. Örneğin İngiltere'de Milli Arşiv 2017 yılında Dijital Stratejisini (Digital Strategy) yayımlamıştır. Bu stratejinin şekillenmesi üç yıllık bir zamana yayılmıştır. Strateji'de dijital dönüşümü yeniden tasarlamak, bu dönüşüme uyumlu iş gücü planlamak, olgunlaştırmak ve çalışanların sayısını çoğaltmak ve süreci olabildiğince hızlandırmak konuları ön plandadır. Burada dijital arşivin teşekkülü, korunması ve doğduğu kaynakla olan bağlamsal ilişkisini güncel tutarak sürekli yenilemek de bulunmaktadır. Aynı zamanda doğduğu kurum ve birimde yapılan tanımlama unsurlarını belgeler arşiv malzemesi olduğu döneme taşıyıp kullanmak gibi hususlara yer verilmiştir. Bu stratejide önemli bir nokta da dijital belgelerin 
kullanıcıya sunumu meselesidir. Belgelerin kullanıcı ile buluşturulma sürecinin yeniden planlanıp geliştirilmesi ele alınmıştır. Web üzerinden yeni sunum hizmetlerinin tasarlanması, erişimde risk oluşturan faktörlerin tespit edilmesi, belgelere erişimi derecelendirerek zaman içerisinde açık hale getirilmesi diğer konular arasındadır (Digital Strategy, 2017). Buna ek olarak İngiliz Milli Arşivinde dijital koruma stratejisinin de geliştirildiğini görmekteyiz (Digital Presevation Strategy, 2017). Farklı ülkelerden insanların ortaklaşa geliştirdikleri platformlar da dikkat çekicidir. Bunun örneklerinden biri Dijital Koruma Koalisyonu (Digital Preservation Coalition) adlı platformdur. Avustralya İngiltere ve İskoçya gibi farklı ülke ve bölgelerden ortakların bulunduğu koalisyon, dijital mirasın güvence altına alınarak korunması için stratejiler geliştirmek, duyarlılığ 1 artırmak, iş gücü ve kapasite geliştirmek, iyi uygulama örnekleri sunmak ve standartlar hazırlamak gibi amaç ve hedeflere sahiptir (Digital Preservationa Coalition, 2021).

Türkiye' de de benzer çalışmalara çok acil ihtiyaç vardır. Özellikle Cumhurbaşkanlığına bağlı Strateji ve Bütçe Başkanlığı içerisinde Bilgi Toplumu Dairesi ve Devlet Arşivleri Başkanlığı gibi e-devlet, e-bilgi ve e-belge konusunda otorite konumundaki idarelere büyük işler düşmektedir. Cumhurbaşkanlığı Kararnamesi ile yeniden teşkilatlanan Devlet Arşivleri Başkanlığı konuyla alakalı daha aktif görevler üstlenebilir. Başkanlık içerisinde kurulan Bilgi İşlem ve Elektronik Arşiv Dairesi Başkanlığına "Başkanlığa devredilecek elektronik ortamdaki arşiv belgelerinin devri hususunda usul ve esasları belirlemek" şeklinde bir takım görevler verilmiş olduğu görülmektedir (Devlet Arşivleri Başkanlığı, 2018). Ancak kontrolümüz dışında son derece hızlı değişen bilgi teknolojisi ürünlerin, belge üretiminden transferine, güvenliğinden dijital devamlılığına kadar çok farklı süreçlerde kullanılmasıyla ilgili olarak daha fazla iş tanımı yapılmalı ve görev üstlenilmelidir. Akademik çalışmalarla konunun önemi ortaya konulmaya çalışılsa (Arısoy, 2018) da yetkili organlar marifetiyle hazırlanacak ulusal bir stratejiye ihtiyaç vardır. Adı geçen kurumlar tarafından ülke düzeyinde açıklanacak stratejiler, kurumlar için model oluşturacaktır. Bu stratejilere göre de örgütler kendi yol haritalarını belirleyebilirler.

\section{E-Belgeler İçin Stratejik Yaklaşım İhtiyacı}

\subsection{E-Belge Uygulamalarında Genel Durum}

Modern yönetim tekniklerini kullanan devletler, halka hizmet götürürken kaçınılmaz olarak bilgi teknolojilerini kullanmaktadır. Çünkü tüm dünyada uzun zamandan beri ülkelerdeki gelişmişlik ölçütlerinden biri kamu hizmetlerini elektronik ortamda internet ağı üzerinden yapabilmektir (United Nations, 2008). İşlemler elektronik ortamda yürütülebildiği ölçüde, hizmetlerin sunumunda zaman ve mekân sınırları ortadan kalkmaktadır. Böylece ülkede hizmet kalitesi yüksek, hesap verebilir, şeffaf ve daha katılımcı bir yönetim anlayışının hâkim olacağı düşünülmektedir.

Bundan dolayı bilgi teknolojisi araçlar, özel işletmelerde olduğu gibi kamu idaresinde de yoğun bir şekilde kullanılmaktadır. Birçok örgüt kurumsal iletişimi elektronik ağlar üzerinde 
işleyen bilgi sistemleri aracılığıyla gerçekleştirmektedir. İlk başlarda bu sistem bir elektronik postadan ibaretken, zaman içerisinde doküman yönetimi uygulamaları ortaya çıkmıştır. İdari ve hukuki alt yapılar tamamlandıkça da elektronik belge yönetimi programlarına dönüşmüştür. Bu programlar, günlük evrak işlerinin hızlıca yürütüldüğü araçlar olduğu kadar yönetici ve çalışanların isabetli kararlar vermesi sırasında gerekli olan doğru bilgiyi hızlı bir şekilde elde etmek için kullandıkları karar destek araçlarıdır.

Günümüzde çoğu kurum EBYS'ye geçmiş ya da geçme aşamasındadır. Bunların bir kısmı her ne kadar bilgi yönetimi sistemi ve doküman yönetimi sistemi şeklinde olsa da hukuki gereklilikten dolayı kamu kurumları daha çok e-imzalı belgelerin üretilip kullanıldığı belge yönetimi sistemlerini tercih etmektedirler. Günümüzde kamu idaresi için bu bir zorunluluktur (Resmi Yazışmalarda Uygulanacak, 2020).

Son dönemde Türkiye'de bu uygulamaların korunması ve güvenliği ile aynı kanallar üzerinden erişim sağlamak konuları daha çok tartışılmaya başlanmıştır. E-bilgi, belge ve dokümanların korunmasıyla ilgili standart niteliğinde çalışmalar yapıldığını görüyoruz. (Elektronik Doküman ve Belge Yönetimi Koruma Profili, 2014). Aynı zamanda bu belgelerin erişim kanallarının önceden belirlenmiş yapılarda olması, böylece kurumlarda aynı üst verilerin kullanılması ön plana çıkan diğer konular arasındadır (Yalçınkaya, 2014).

EBYS'lerin iyileştirilmesi için Türkiye'de bunlar olurken, dünyada da birçok gelişme yaşanmaktadır. Çeşitli projeler hazırlanmakta, akademik yayınlar yapılmakta, prosedür ve rehber niteliğinde el kitapları çıkarılmaktadır. Bunların ilk örnekleri, elektronik ortama taşınan kurumsal iş süreçleri sonunda ortaya çıkan elektronik bilginin hangi şartlarda doküman ve belge özelliği taşıdığıyla ilgilidir (Duranti, 1995, s. 8). Ardından, araştırmacılar ve mesleki kurumlar, elektronik belgelerin güvenilirliği bakımından idari, tarihi ve hukuki nitelikleri (MacNeil, 2000; Duranti ve Rogers, 2012, s. 524-26) 1şığında bütünlügünün sağlanması ve onu temin edecek kimlik tespiti aracı olarak e-imzanın kullanılması ile farklı dönemlerde özgünlüğü korumak konuları üzerinde durmuşlardır (InterPARES, 2002; Boudrez, 2007, s. 179-193).

Tüm bu tartışmaların yanı sıra ulusal ve uluslararası düzeyde çeşitli dokümanların yayınlandığına şahit oluyoruz. İngiliz Milli Arşivinin çıkardığı Elektronik Belge Yönetimi Sistemleri için Gereksinimler (Requirements for Electronic Records Management Systems) (The National Archives, 2002) adlı çalışmada, kurulacak elektronik belge yönetimi sistemlerinin taşıması gereken özellikler ile sahip olması gereken temel sistem dinamikleri açıklanmıştır. Kısa adı MoReq olan ve Elektronik Belge Yönetimi İçin Model Gereksinimleri (Model Requirements for Electronic Records Management) (DLM Forum Foundation, 2010) adını taşıyan başka bir rehberde ise yine elektronik belge yönetimi programlarının yürütülmesinde başlıca koşulların neler olması gerektiği bir model önerisi şeklinde takdim edilmektedir. EBYS'lerde kullanılacak uygulama yazılımlarının sahip olması gereken kriterler için ise DoD5015.2-STD (2007) adıyla 


\section{Elektronik Belge Yönetimi Uygulama Yazılımı Hazırlama Kriterleri Standardı (Electronic} Records Management Software Application Design Criteria Standart) çalışmasını görüyoruz.

Mevzuat, idari prosedürler ve standart çalışmalarının ardından gerek kurumların kendi öz kaynaklarıyla ürettikleri ve gerekse özel firmaların geliştirdikleri uygulama yazılımı ürünlerini ortaya çıkarmıştır. Kurumların ve EBYS ile ilgilenen işletmelerin tedarik ettiği bu ürünler, elektronik belge yönetimi sisteminin temel yapı taşını oluşturmaktadır. Üzerlerinde bir takım teknik ve idari çalışmalar yapılarak kullanılacak kuruma uygun hale getirilen bu yazılımlar ile örgütler kendi sistemini kurmaktadır. Bugün elektronik belge üretip e-imzalı uygulama başlatarak, kâğıtsız ofisler kurmaya aday birçok idarenin var olduğunu biliyoruz. Üniversitelerden bakanlıklara valilik ve kaymakamlık gibi il idarelerinden belediyelere kadar birçok kurum bunun üstesinden gelmiştir. Bunun ilk örneklerini Kalkınma Bakanlığı, İçişleri Bakanlığg, Sağlık Bakanlığı, Orman ve Su İşleri Bakanlığı (Tarım ve Orman Bakanlığı) gibi kurumlar oluşturmaktadır. Ankara Üniversitesinde ilk başlarda fiziksel arşivin düzenlenmesi ve belge yönetimi sisteminin kurulmasıyla başlayan çalışmalar, e-imzalı elektronik belge yönetiminin kurulup işletilmesiyle devam ettirilmiştir. Ardından İstanbul'da Marmara Üniversitesi ve İstanbul Üniversitesi, sonrasında birçok üniversitenin elektronik belge yönetimi hizmetlerini başlattıklarını görmekteyiz. Bugün için EBYS'ye geçmeyen üniversite yok gibidir. Diğer taraftan İstanbul'da Büyükşehir Belediyesi başta olmak üzere ilçe belediyelerinden Bağcılar, Başakşehir, Üsküdar, Zeytinburnu, Eyüp, Adalar, Pendik, Fatih ve Tuzla gibi birçoğunun e-imzalı uygulamalara geçtiğini biliyoruz (Çiçek, 2013, s. 873-79). Bunların sayısını çoğaltmak mümkündür. Fakat iyi niyetli bu teşebbüslerde özellikle kurumsal değişim ve dönüşümün doğru yönetilemediği de bir gerçektir. İnsanların alışkanlıklarından vazgeçmek istememeleri, kurumun katı bürokrasiyi aşamaması, sanal ortamdaki bilgiye güvensizlik ve teknolojik alt yapının yetersizliği değişimin önündeki başlıca engellerden bir kaçıdır.

Her ne kadar belirtilen güçlükleri aşmak adına standartlar çıkarıldığı bilinse de koşullar ülkelere göre değişebilmektedir. Elektronik doküman yönetimi sistemi uygulamalarının başarısı için değişim yönetimini (ISO/TR 14105:11, 2011) amaçlayan standartlar güncel dönemdeki e-belgelerle ilgili yol gösterici olabilirken, ilk üretildiği gibi sürekli muhafaza ve erişimi mümkün kılmak adına arşivlenen e-belgelerle alakalı nasıl bir strateji yürütülmesi gerektiğini tam bilemiyoruz. Özellikle Türkiye'de e-belgeleri uzun vadede bekleyen tehditlerin neler olabileceğiyle ilgili teorik ve akademik çalışmalar yapılmasına rağmen giderilmesine yönelik yol haritası henüz çok da belirgin değildir.

\subsection{Türkiye'de E-Belgeleri Bekleyen Tehditler}

Birçok kurumda arşivlenen e-belgelerin üzerinden henüz uzun yıllar geçmediği için mevcut durum kontrol edilebilir gözükmektedir. Buna karşın, özellikle güncel dönemde oluşan belgelerin kullanılma koşulları, yarın doğabilecek risk ve tehditlerin ipuçlarını bize göstermektedir. 
Teknolojik donanım ve yazılımın sahip olduğu kırılganlık, sürekli değişen ve gelişen yapılar, bugün kullanılabilen belgelerin yarınları için öngörülebilir kararlar almayı güçleştirmektedir.

Farklı kurumlarda yapılan yerinde gözlem ve iş gezisi şeklindeki ziyaretler sırasında değişime karşı dirençler olduğu gözlenirken, EBYS'ye geçen kurumlardaki uygulama yazılımlarının bir kısmının Türk Standartları Enstitüsünden (TSE) TS 13298 Standardı sertifikası bulunduğu, bazılarının ise böyle bir sertifikaya sahip olmadıkları görülmüştür (Çiçek, 2016, s. 413-415). Oysa 16 Temmuz 2008 tarihli ve 26938 sayılı Resmi Gazete'de yayımlanan Başbakanlık Genelgesi'nde “Kamu kurum ve kuruluşları oluşturacakları elektronik belge yönetim sistemlerinde TS 13298 no'lu standarda göre işlem yapmaları gerektiği” belirtildiğinden, EBYS'ler için kullanılacak yazılımlarda bu Standard'ın sertifikası aranmalıdır. Buna ră̆men yüzlerce kurumda Standart'a sahip olan ve olmayan birçok uygulama yazılımı bulunmaktadır. $\mathrm{Bu}$ yazılımları kullanılarak idari işlerde e-belge üretilmekte, kayıt, havale ve işlem gibi iş süreci adımları gerçekleştirilmekte, işlemi biten belgeler dosyalanmakta, saklama planına göre de arşivlenmektedir. En azından Sertifikası bulunan yazılımların elektronik belgenin yaşam döngüsündeki bu fonksiyon adımlarını gerçekleştirmesi beklenmektedir. Dolayısıyla bu yazılımların sisteme ait bir takım kuralları doğru işletiyor olması gerekir.

Sınırlı sayıda kurum üzerinde yapılan saha çalışmasında özellikle Sertifikası bulunmayan uygulama yazılımlarında bir takım aksaklıkların yaşandığı gözlenmiştir. Bunların bir kısmının sistemin doğru planlanıp işletilmemesinden kaynaklandığı görülürken, bazılarının ise yazılımsal problemler olduğu fark edilmiştir (Çiçek, 2016, s. 409-424). Bu problemlerden öne çıkanlar yazılım dilinin geliştirilmeye müsait olmaması, veri tabanlarındaki kodlama girişlerinde standardın bulunmaması, dijitalleştirme yapılırken kayıt formatı tercihlerindeki yanlışlıklar, yazılımın dokümantasyonunun hazırlanmaması ya da yetersiz olması, farklı yazılımlarla entegrasyonun sağlanamamasıyla alakalıdır (Çiçek, 2016, s. 417-424). Bundan dolayı, kamu idarelerinde kurulan, kurulma aşamasında olan veya projelendirilen sistemlerin elektronik belge yönetimi yaşam döngüsündeki sistem kriterlerini sağlayıp fonksiyonları ne ölçüde gerçekleştirebildikleriyle alakalı olarak birçok soru akla gelmektedir. En başta elektronik ortamda üretilen ve işlem gören ya da kâğıt olarak üretildikten sonra sisteme dâhil edilen belgelerin bütünlügünün korunması ne kadar mümkün olmaktadır. Henüz yeteri kadar cevaplanmamış buna benzer sorulardan dolayı e-belgelerin ilk üretildiği şekliyle orijinal ve otantik olarak ve tüm diplomatik özelliklerini (Çiçek, 2009, s. 135-191) koruyarak varlığını muhafaza etmeleri durumu uzun vadede birçok risk barındırmaktadır.

Oysaki idari ve hukuki işlemlerde ilk önceliklerden biri doğru, güvenilir ve otantik belgeler üzerinde işlem yapmaktır. O hâlde her dönem e-belgelerin güvenilirliğini korumak gerekir. Bu yüzden faklı ülkelerde evrak içeriğinin orijinalliğini korumak, doğrulamak ve evrak üzerinde yapılmış olan değişiklikleri tespit etmek için bir takım projeler yürütülmesi, bahsi geçen risklerin devam ettiğini göstermektedir (InterPARES Trust: Research Studies, 2020). Örneğin; “E-imza 
ve zaman damgası gibi araçların kullanımıyla ilgili olarak teknolojik devamlılığı sağlamanın planlaması yapılmış mı?”, "Kurum veya firma değişikliğinde e-güven hizmetinin sürekliliği nasıl sağlanacak?”, "Kurumlarda yönetilebilir bir dosya ve saklama planı bulunmakta mı?”, "Bunu yönetecek uzman personel var mı ve EBYS'de bu planlanmış mı?”, "Kurumlar altı ay veya bir yıl gibi belirli süre (Resmi Yazışmalarda, 2020) içerisinde sistemlerine entegre ederek kullanmak durumunda oldukları e-Yazışma Teknik Rehberi (2020) türünde uygulamaları başarıyla hayata geçirebildiler mi?", "Sistem, üretilen belgelerin bütünlüğünü sağlamayı taahhüt etse de uygulama sonrasında bunun gerçekleştirilmesinin ne ölçüde mümkün olduğu?" gibi soruların cevabı planlanmış senaryolar gerektirmektedir. Örneğin belge ile beraber üretilen e-imza, zaman damgası gibi unsurlar ile belgenin türe özel temel form hususiyetlerinin, üretildiği dönemdeki gibi bütünlük içerisinde muhafaza edilip edilmediği, edilmeme durumu karşısında sistem yapıcı ve uygulayıcıların alternatif olarak başka planlarının olup olmadığı bilinmemektedir. Her ne kadar kurumlardaki EBYS'lerin TS 13298 Standardında yer alan kriterleri karşılaması gerektiği değerlendirilip (Yılmaz, 2012), birkaç kurumda da sistemin yine aynı standarttaki koşulları karşılayıp karşılamadığı incelense (Eroğlu ve Külcü, 2014) de bu çalışmalar Türkiye genelini yansıtmamaktadır. Tüm bu soruların cevabı saha araştırması yapılarak detaylı şekilde açığa çıkarılmamıştır. Bu yüzden EBYS çıktısı olan e-belgelerin durumunun ne olduğu sorusu ülke düzeyinde araştırılmayı beklemektedir.

Bu belgelerle ilgili olarak güncel safhada birçok soruya cevap aranırken, arşiv malzemesi olduğunda bizi ne gibi zorlukların beklediğini henüz tam bilemiyoruz. Tehdit olarak karşımıza çıkan ilk unsurlardan biri belgelerin formatı ve taşındığı ortamdaki farklılıktır. Aynı zamanda bunları yazılım ve donanım itibariyle teknolojik göç ettirmenin ne kadar mümkün olduğudur. Oysa e-bilginin tutulduğu her alanda teknolojiyi göç ettirerek yeni sistemlere uyum bir zorunluluktur (Long-Term Storage and Migration of Electronic Records, 2015). Örneğin 2000'li yıllarda yapılan bir araştırmanın sonuçlarının yayınlandığı yazıda, elektronik belgelerin yaklaşık \%55'inin CD, DVD, hard disk ya da taşınabilir şekilde tek bir depolama ortamında tutulduğu görülmüştür (Lyman ve Varian, 2000). Bu konuda çözüm bekleyen birçok problem bulunmaktadır. Uzmanlar da bir taraftan deneyimlerini paylaşmakta, öneriler sunmaktadır. Gönümüzde e-belgelerin devamlılığını sağlamakla alakalı gündemdeki tartışmalar genellikle dijital süreklilik, delil değerleri ve özgünlük gibi ortak konular üzerine odaklanmaktadır. O halde çözüm önerileri de paylaşılmalıdır (Asogwa, 2012, s. 201-204).

Tüm bu risk ve tehditler sebebiyle, arşiv boyutu çok iyi planlanmayan e-belgelerle alakalı olarak üretildiği fonksiyonel kaynağın ve arşivsel bağın kopma tehlikesi bulunmaktadır (Duranti, 2007; Çiçek, 2011a, s. 99). Arşivsel bağın kopması, saklama süresi sonunda arşive devredilen malzemenin geldiği kaynağının yeteri kadar bilinememesi ve emanet zincirinin kurulamaması demektir. Böylece belgelerin provenansının tehlikeye girmesi söz konusudur. Her ne kadar prosedürlerde belge hiyerarşisinin (TS 13298, 2015) korunması gerektiği özellikle 
belirtilse de uygulamada buna çok da dikkat edilmediği saha çalışmaları sırasında görülmüştür. Bir takım olumsuzluklar, henüz güncel safhada yaşanabiliyorsa, belgeler arşiv malzemesi olduğunda provenansının korunmasında da çeşitli problemlerin bizi beklediği oldukça açıktır. Dolayısıyla belge hiyerarşisini sağlayamayan sistemlerde, arşivsel bağ kurulamayacağı için arşiv malzemesinin provenansını anlayamama tehlikesi uzak bir ihtimal değildir.

Kurumlarda e-belge üretimi, elektronik belge yönetimi, doküman yönetimi, e-imza ve mobil imza (m-imza) destekli belge yönetimi, elektronik arşiv yönetimi ve kâğıt belgelerin sayısallaştırılması şeklindeki projeler neticesinde gerçekleşmektedir. Yüklü bütçeler ayrılmasına rağmen bir takım projelerin başarılı olamadığı da bir gerçektir. Bunun bir sebebi, özellikle kurumların bu yazılımları tedarikleri sırasında hazırlamış oldukları şartnamelerdeki eksikliklerdir. Daha açık bir ifadeyle, yukarıda açıklanmaya çalışıldığı gibi EBYS'de kullanılacak uygulama yazılımında bulunması gereken özellikler, önceden çok da belirgin olarak ortaya konulmamış olabilmektedir. Ürün daha baştan eksiklikleriyle gelmektedir. Birçok EBYS ihalesinin iş yürütme şartnamelerinde özellikle arşiv ve belge yönetime ilişkin fonksiyonların doğru yansıtılmadığ (Güler, 2020, s. 103). Diğer taraftan iyi bir şartname de olsa ne yazık ki işi gerçekleştirme safhasında burada geçen şartların bir kısmına uyulmadığg/uyulamadığı da konunun diğer bir yönüdür. Şartnamedeki hükümler kısmen yeterli olsa da işi gerçekleştirme sürecinde tedarikçi firmanın bunu yeterince yerine getiremediği vakalarla da karşılaşılmaktadır. Uyarmalara ve müdahalelere rağmen, iyileştirilmelerin istenildiği şekilde yapılamadığı; dolayısıyla bir takım işlerin eksik kabul edilmek durumunda kalındığı da bilinmektedir. Bu durumun bir sebebinin de özellikle kurum içerisinde işi takip edecek teknik ekibin yeterli olmamasından kaynaklandığı görülmüştür (Çiçek, 2011a). Bu tür problemleri açığa çıkaran -birkaç kurumla ilgili sınırlı da olsa- yayınlar yapılmıştır (Önaçan, 2012, s. 1-26; Özdemirci ve Alyakut, 2012, s. 557-564; Güler, 2020, s. 85-104 ). Her gün hem firsatları hem de tehditleri çoğalan e-belgelerin sürdürülebilirliğinin sağlanması için ülke düzeyinde bir durum tespitinin bir an önce yapılması zarurettir. Böylece aynı ve benzer hatalara tekrar düşmemek adına bundan sonra nelerin yapılması gerektiği açıklanmış olacaktır.

Diğer taraftan, özellikle TS 13298 sertifikası almış olan uygulama yazılımı ürünler kullanılarak yönetilen elektronik belgelerin arşiv boyutu hakkında çok da detaylı bilgiye sahip değiliz. Bu sertifikayla birçok sistem kriterini barındırdığı düşünülen yazılımların uygulamada neler yapabildikleri; diğer bir ifadeyle, makale niteliğinde bir iki deneme (Eroğlu ve Külcü, 2014) olsa da sistem normlarını gerçekçi olarak ne kadar uygulamaya yansıttıkları henüz yeteri kadar ele alınmamıştır. Çoğu sistemin kurulma aşamasında olduğu, birçok eksikliğin uygulama safhasında çözülebildiği göz önünde bulundurulursa, belki de bu tespitin çok erken olduğu düşünülebilir. Fakat arka planda yüzbinlerce belge e-imzalı, zaman damgalı veya doküman olarak üretilmeye devam etmektedir. 


\subsection{E-Belge Stratejisi}

Güncel safhada EBYS'lerin sağladığı kolaylık sayesinde işler önceki uygulamalara göre daha hızlı ve kontrollü yürütülebildiği için e-belgelerin akıbetiyle ilgili sorularla şimdilik çok da ilgilenilmemektedir. Ancak, bir arşivci ileride kendi kullanacağı malzemeyi şimdiden düşünmek zorundadır. Bugün kurumlar e-belgenin avantajlarını yaşarken, yarın çıkabilecek muhtemel problemlerle arşivciler yüz yüze kalacaktır. Elektronik belgelerin arşiv değeri kazanıp uzun süre saklanmaları söz konusu olduğunda özniteliklerinin korunmasıyla ilgili çözüm yolları şimdiden düşünülmelidir. Hatta bu konu, daha belge üretilirken göz önünde bulundurulmalı, arşivleneceği dönem beklenmemelidir. Çünkü baştan olması gerektiği gibi üretilmeyen belgelerin, sonradan orijinalliğini korumak da zorlaşacaktır. Bu yüzden üretimden sürekli saklanmaya kadar her dönem belge ve dosyaların bütünlüğünün devamlılığı için stratejiler geliştirilmelidir (Isa, A. M. 2011, s. 397-99).

Her ne kadar bilgi güvenliği konusunda çeşitli standartlar bulunup stratejiler geliştirilse de e-belgelerin özniteliklerini sürekli korumakla ilgili bir politikaya henüz rastlayamıyoruz. Durum böyle olunca, ne yazık ki bu konuda kısa ve uzun vadeli planlar da pek yoktur. Çoğu yerde belirsizlikler devam etmektedir. Dolayısıyla bir e-imzalı belgenin elli yıl sonraki durumuyla ilgili öngörüde bulunmak pek imkân dâhilinde değildir. Geliştirilen bir takım belge yönetimi sistemlerinin arşiv modülünün dahi bulunmaması bunun açık göstergesidir. Oysa Odabaş'ın (2010) da belirttiği gibi e-devlet için geliştirilen bilgi sistemlerinin ürünü elektronik belgeler kurumsal gereksinimleri karşılayacak şekilde günün koşullarına cevap verebilmelidir. Durum böyle olmasına karşın, ne yazık ki çoğu kurumda belgeler elektronik ortamda üretilirken arşiv boyutunda ortaya çıkacak ihtiyaç ve zorunluluklar bizleri henüz meşgul etmemektedir. Yine Odabaş'ın aktardığına göre bunun sonucunda gerek kurumlarda gerekse arşivlerde saklanan elektronik ortamdaki kayıtların bir kısmı daha şimdiden erişilemez durumdadır. Bunu da Kanada örneğini vererek açıklamaktadır. 2010'da yayınlanan bir çalışmada Kanada'da kamu kurumlarındaki dijital içeriğin \%10'una erişimin daha şimdiden mümkün olmadığ belirtilmektedir.

Konuyla ilgili olarak Türkiye'deki durum yeteri kadar açık değildir. Çünkü Türkiye'de kurumların elinde bulunan elektronik belge potansiyelinin nitelik ve niceliği hakkında kayda değer bilgi yok denecek kadar azdır. Bu konuda tüm kurumları kapsayan bir saha araştırması da bulunmamaktadır. Birkaç kurumdaki e-belge uygulamalarıyla alakalı çalışmalardan kanaat oluşturulmaya gayret edilmektedir. En azından geneli yansıtacak kadar belli sayıda kurumda saha araştırması yapılabilir. Buralardan elde edilecek verilerin değerlendirilmesinin ardından ölçülebilir sonuçlar çıkarılabilir. Kurumlar üzerinde gerçekleştirilecek bir "e-belge envanterine" ihtiyaç bulunmaktadır. Mevcut uygulamaları ve çıktı olarak ortaya konan e-belge yapıları bilinmelidir. Böylece hem kurum hem de ülke düzeyinde çeşitli adımların daha doğru atılması mümkün olacaktır. Böyle bir envanterin çıkarılması, e-belgelerin sürekliliğiyle ilgili strateji 
geliştirmeye imkân verecektir. Aksi halde e-belgelerin akıbeti hakkında Türkiye'de uzun vadeli öngörülerde bulunmak oldukça zor gözükmektedir.

Elektronik sürdürülebilirlik, gerektiği zamanda ve ihtiyaç olduğunda e-bilgiyi her an kullanılabilir şekilde hazır tutabilmektir (Understanding Digital Continuity, 2017). Sürdürülebilirlikle ilgili temel dinamikler ise e-bilginin bulunduğu taşıyıcı, onu okuyacak uygun yazılım ve bunu işletebilecek donanım şeklinde tasnif edilebilir. Geliştirilecek stratejide bu hususlara odaklanmak gerekecektir.

Farklı ülkelerin bu konuya ilişkin geleceğe dönük planlar yaptıklarını görüyoruz. Mesela Avusturya Milli Arşivi, Elektronik Sürdürülebilirlik 2020 Politikası'nı belirlemiştir. Bu politika kapsamında Arşiv, kamu kurumlarındaki elektronik bilginin yönetimiyle ilgili mevcut durumu tespit ederek, bunların iyileştirilmesi için yapılacak olanlarla ilgili tavsiyede bulunmaktadır (Digital Continuity 2020 Policy, 2015). Dünyada bunlar olurken Türkiye'de hızlı bir şekilde hayatımıza giren e-belgelerin kullanımında devamlılığı sağlamak için bir takım stratejilere acil ihtiyaç bulunmaktadır. Bununla birlikte, geliştirilecek kısa ve uzun vadeli stratejiler kesin bilgilere dayanmalıdır. Bu da öncelikle bir durum tespitini gerektirmektedir. Düşünülen planlarda bu veriler kullanılacaktır. Dolayısıyla öncelikle ülkedeki e-belge potansiyelinin bilinmesi ve buna uygun stratejiler geliştirilmesi, doğru bir yöntem gibi gözükmektedir. $\mathrm{Bu}$ tespitle e-belgelerin bütünlüğünün ve güvenirliğinin ne şekilde sağlandığı, bunu sağlamak için kullanılan kimlik tespiti ve güvenlik araçlarının neler olduğu görülecektir. Kurumların uzun vadeli koruma sürecinde aldıkları güvenlik tedbirleri ve yaptıkları ya da yapmadıkları planlar açığa çıkacaktır.

Belgelerin yaşam döngüsüne bakıldığında, tasfiye işleminin bir boyutu da milli arşivleri ilgilendirmektedir. Sürekli saklanması gereken belgelerin bir kısmını kamu kurumları kendi arşivlerinde tutarken, diğer kısmının da bu arşive devri söz konusudur. Ancak, bu süre sonunda neyin, hangi formatta devredileceği, belge hiyerarşisinin tam olup olmadığı ve dosya bütünlüğünün ne kadar sağlanmış olduğu çok da belirgin değildir. Örneğin daha öncede ifade edildiği gibi kamu kurumları ve kuruluşları arasında iletilen üstyazı ve metin tabanlı ekler için ISO/IEC 19005-1:2005 Standartına göre PDF/A fotmatında, sayısal grafik ve diyagramlar için “.gif”, sayısal fotoğraflar için ise “.jpg”, “.jpge” formatında belge üretmekle ve yine kendilerine gönderilenleri de aynı formata entegre etmekle yükümlü oldukları belirtilmektedir (Birlikte Çalışabilirlik Esasları, 2012). Durum böyle olmasına rağmen kısmen bilgi sahibi olsak (Yazıcı ve Özdemirci, 2019, s. 95-111; Dişli ve Özgür, 2019, s. 25-44 ) da ülkede kaç kurumun adı geçen formata uygun belge ürettiğiyle ilgili kesin bir malumata sahip değiliz. Sahadaki örneklere bakıldığında çok farklı formatlarla karşılaşmak mümkündür. Diğer taraftan arşivlerin bu konuda ne tür bir hazırlığının olduğunu da bilemiyoruz. Oysa elektronik belgeler arşivde tutulduğunda gerçekliğinin ve bütünlüğünün korunması ve erişiminde devamlılığın (Xie SL, 2012) sağlanması kaçınılmaz bir durumdur. 
Kurumlarda hayata geçirilen EBYS projelerinin, hız, verimlilik, güvenilirlik, kişilere bağımlılığ 1 önlemek, daha kaliteli iş üretmek ve hizmet odaklı olmak gibi birçok güçlü yönü bulunmaktadır. Ancak, bilgi teknolojisi yazılım ve donanım ürünlerine bağımlılıktan kaynaklanan zayıf tarafları da göz ardı edilemeyecek kadar çoktur. Yazılımların açık kaynak kodlu olmaması, işletim sistemleri ile uygulama yazılımı ürünlerin güncellenme ihtiyacının bulunması ve bunun lisanslı bir takım ürünlere bağımlı olması, serbest piyasa ekonomisi ve rekabet ortamında bilgi teknolojisi ürünlerin teknoloji pazarında çok hızlı değişikliğe uğraması ve çoğu zaman kamu kurumlarının bu değişimi takip edememeleri, yine kurumların teknolojiyi göç ettirmek noktasında sağlıklı yürüyen bir stratejilerinin olmaması gibi birçok zayıf yönü ortaya çıkarmaktadır.

\section{SONUÇ VE ÖNERILER}

Bilgi teknolojilerinin hızlı gelişmesiyle günlük iş yaşamının temel enstrümanları haline gelen belge yönetimi sistemleri, sağladığı avantajların yanı sıra bir takım dezavantajları da beraberinde getirmiştir. Bu dezavantajlardan biri, güncel olarak kullanılan e-belgelerin uzun dönemde akıbetlerinin ne olacağı, devamlılıklarının nasıl sağlanacağı konusudur. Toplumun bilgi birikimi ve kültür mirası olarak ülkenin hafızası konumundaki kayıtların erişilememe ve hatta yok olma ihtimali, karar mekanizmalarını bir an önce planlar yapmaya zorlamaktadır.

Tüm dünyada olduğu gibi Türkiye'de de e-belgelerin kullanımında sürdürülebilirliği sağlamak için bir takım çalışmalara acil ihtiyaç bulunmaktadır. Fakat geliştirilecek kısa ve uzun vadeli stratejiler, kesin bilgilere dayanmalıdır. Bu da öncelikle bir durum tespiti ile mümkün gözükmektedir. İlk başta ülkenin e-belge potansiyelinin bilinmesi gerekmektedir. $\mathrm{Bu}$ tespit ile örgütlerde e-belgelerin bütünlüğünün ve güvenirliğinin ne şekilde sağlandığı, bunun için kullanılan sistem ve güvenlik araçlarının neler olduğu görülecektir. Aynı zamanda dijitalleştirilen belgelerin format yapıları, ne kadarının uluslararası geçerliliği bulunan lisanlı standartlara sahip olduğu, ne kadarının bunun dışında kaldığı anlaşılacaktır. E-belgelerin uzun vadeli korunması sürecinde kurumların aldıkları güvenlik tedbirleri ve yaptıkları ya da yapmadıkları planlar açığa çıkacaktır. İşte geliştirilmesi düşünülen stratejilerde bu veriler kullanılacaktır. Dolayısıyla öncelikle ülkedeki e-belge potansiyelinin bilinmesi önemlidir.

Kurumlar üzerine yapılan birkaç çalışma irdelendiğinde, bunların ülke düzeyinde politika belirlemeye ve stratejik kararlar almaya imkân verecek yeterlilikte olmadıkları görülmüştür. Dolayısıyla kısa ve uzun vadeli planlar hazırlamak için daha kapsayıcı çalışmalara ihtiyaç vardır. Her ne kadar sınırlı sayıdaki birkaç gayret sonucunda ortaya çıkan bilgiler, konu edilen kurumların uygulamalarına 1şık tutsa da tespitlerin kamu idaresinin bütün kurumları için aynı nitelikte olduğunu düşünmek pek mümkün değildir.

Elektronik belgelerin uzun süre güvenli bir şekilde saklanmaları konusunda stratejiler çok geçmeden geliştirilmelidir. Başka bir değişle, kurumlar bugün sahip oldukları e-belgelerin uzun 
dönemde özniteliklerini nasıl koruyacaklarını gösterecek yöntemleri planlamalıdır. Böylece e-belgelerin sürdürülebilirliği için bir yol haritası çıkarılmış olacaktır.

E-belgelerin geleceği konusunda karar almak için bir problem çıkmasını beklemek uzun vadeli çözümleri geciktirebilir. Diğer taraftan ulusal veya uluslararası bir siber saldırı ihtimali kurumları rahatsız etmeye devam etmektedir. Risk ve tehditler şimdiden öngörülebiliyorsa, çözümler de düşünülmelidir. Sağlam bir aracın güvenliğini sağlamanın masrafı, bozulmuş hatta geri döndürülmesi yeniden üretilmesinden kat ve kat daha zahmetli olan bir aracın maliyeti ile şüphesiz kıyaslanamaz. Kaldı ki yok olması durumunda telafisinin neredeyse mümkün olmadığı düşünülürse, birçok güçlüğe şimdiden göğüs germek daha akıllıca olacaktır. O halde e-belgelerin geleceğiyle ilgili olarak riskler şimdiden öngörülüp, çözüm için gerekli stratejiler geç kalınmadan hazırlanmalıdır.

Hakem Değerlendirmesi: Dış bağımsız.

Çıkar Çatışması: Yazar çıkar çatışması bildirmemiştir.

Finansal Destek: Yazar bu çalışma için finansal destek almadığını beyan etmiştir.

Peer-review: Externally peer-reviewed.

Conflict of Interest: The author has no conflict of interest to declare.

Grant Support: The author declared that this study has received no financial support.

\section{Kaynakça/References}

Arısoy, Y. E. (2018). Türkiye'de Elektronik Belge Yönetiminde Milli Arş̧iv Politikalarının Gelişstirilmesi (Yayınlanmamış doktora tezi). Ankara Üniversitesi Sosyal Bilimler Enstitüsü Bilgi ve Belge Yönetimi Anabilim Dal1, Ankara.

Arısoy, Y. E. ve Özdemirci, F. (2017). Kurum ve kuruluşların bakış açısından e-belgelerin arşivlenmesi. DTCF Dergisi, 57(2), 1250-1270.

Asogwa, B. E. (2012). Preservation and access in an age of e-science and electronic records: Sharing the problem and discovering common solutions. Records Management Journal, 22(3), 198-211.

Ataman, B.K. (2005). Elektronik ortamdaki bilginin arşivlenmesi. M. E. Küçük (Yay. haz). Prof. Dr. Nilüfer Tuncer'e Armağan içinde (s. 78-100). Ankara: Türk Kütüphaneciler Derneği.

Borglund, Erik A. M. ve Anderson, K. (2011). Lost records: The consequence of inadequate recordkeeping strategies. Databases and Information Systems VI: Selected Papers from the Ninth International Baltic Conference (s. 271-282) içinde. Latvia: Latvia University.

Boudrez, F. (2007). Digital signature and electronic records. Archival Science, 7, 179-193.

Çiçek, N. (2009). Modern Belgelerin Diplomatiği. İstanbul: Derlem.

Çiçek, N. (2011a). Elektronik belgelerin diplomatik analizi ve arşivsel bağın kurulmasındaki önemi: Türkiye’deki uygulamalar ışı̆̆ında bir inceleme. Bilgi Dünyası, 12(1), 87-104. 
Çiçek, N. (2011b). Örgütlerde elektronik belge yönetimi programlarının kurulmasında bilgi ve belge uzmanlarının rolü: e-Belediyecilik örneği. Z. Parlak ve İ. G. Yumuşak (Ed.), International $9^{\text {th }}$ Conference on Knowledge, Economy and Management Proceedings (s. 109-119) içinde. Sarajevo: Garmond.

Çiçek, N. (2013). Electronic records management projects in e-transformation Turkey practices: A study on district municipalities in İstanbul. İ. Yumuşak (Ed.), $11^{\text {th }}$ International Conference on Knowledge, Economy and Management (s. 869-885) içinde. İstanbul: BEYKOM.

Çiçek, N. (2016), Belediyelerde dijital devamlılı̆̆ tehdit eden yazılıma dayalı sorunlar. B. Yılmaz, T. Çakmak ve Ş. Eroğlu (Yay. haz.), Belediyelerin Kütüphane ve Arşiv Hizmetleri Uluslararası Sempozyumu (s. 409428) içinde. Bursa: Nilüfer Belediyesi.

Çiçek, N. (2020). E-devlet stratejisi bağlamında elektronik belge yönetimi için "yazılı politika" gereksinimi: Türkiye'deki uygulamalar üzerine bir inceleme. Türk Kütüphaneciliği, 34(3), 377-405.

Devlet Arşivleri Başkanlığı Hakkında Cumhurbaşkanlığı Kararnamesi. (2018, 16 Temmuz). Resmi Gazete (Say1: 30480). Erişim adresi: https://www.resmigazete.gov.tr/eskiler/2018/07/20180716-1.pdf

Digital Preservation Coalition. (2021). Erişim adresi: https://www.dpconline.org/

Dişli, M. ve Külcü, Ö. (2019). Elektronik belge yönetim sistemlerinde birlikte çalışabilirlik: Türkiye'deki koşullar üzerine bir değerlendirme. B. Yalçınkaya, M. A. Ünal, B. Yılmaz ve F. Özdemirci (Ed.), Bilgi Yönetimi ve Bilgi Güvenliği: e-Belge-eArşiv-eDevlet-Bulut Bilişim-Büyük Veri-Yapay Zekâ (s. 25-44) içinde. Ankara: Ankara Üniversitesi Bilgi Yönetim Sistemleri Belgelendirme ve Bilgi Güvenliği Merkezi.

DLM Forum Foundation. (2010). Modular Requirements for Records Systems. J. Garde (Ed.), Core Services \& Plug-in Modules. Erişim adresi: http://bookshop. europa.eu/ en/moreq2010 -modular-requirementsfor-records-systems-pbKAAF11S01/

DoD5015.2-STD. (2007). Electronic records management software application design criteria standart. Erişim adresi: http://www. Dtic. Mil/whs/ directives/ corres/pdf/501502std.pdf

Dorsey, P. (2005). Top 10 reasons why systems projects fail. Erişim adresi: http://www.hks. harvard.edu/mrcbg/ ethiopia/ Publications/ Top \% 2010\% 20Reasons \%20 Why\% 20Systems \%20 Projects \%20 Fail.pdf

Duranti, L. (1995). Reliability and authenticity: The Concepts and their implications. Archivaria, 39 (Spring), 5-10.

Duranti, L. ve Guercio, M. (1997). Research issues in archival bond. Electronic Records Meeting. Erişim adresi: http://www.archimuse. com/erecs97/s1-ld-mg.HTM

Duranti, L. ve Rogers, C. (2012). Trust in digital records: An increasingly cloudy legal area. Computer Law and Security Review, 28, 522-531.

Eroğlu, Ş. ve Külcü, Ö. (2014). TS 13298 çerçevesinde kurumsal bilgi sistemleri ve elektronik belge yönetimi standartlarının değerlendirilmesi: İçişleri Bakanlığı örneği. Bilgi Dünyası, 15(2), 327-352.

Güler, C. (2020). Kamu kurumlarındaki EBYS yazılımlarının TS 13298 fonksiyonel kriterlerine uygunluğu. Bilgi ve Belge Araştırmaları Dergisi, 14, 85-104.

International Council on Archives. (2016). Digital preservation in lower resource environments: A core curriculum. Understanding digital records preservation initiatives ICA (International Council on Archives) and IRMT (International Records Management Trust). Erişim adresi: https:/www. ica.org/ sites/ default/ files/Digital\% 20Preservation\% 20Initatives\% 20Module_0.pdf

INTERPARES Trust. (2020). Research studies. Erişim adresi: https://interparestrust. org/trust/about_research/studies

INTERPARES. (2002). Authenticity task force. Erişim adresi: http://www. interpares. org/book/ interpares_ book_d_part1.pdf 
Isa, A. M. (2011). Strategic management of records and risks for the sustainability of organizations. AsiaPacific Conference Library and Information Education and Practice, (s. 393-403) içinde. Erişim adresi: http://ir. Uitm. Edu. My/ 3964 /1/ SP_SMO11_42.pdf.

ISO/TR 14105. (2011). Document management-change management for successful electronic document management system (EDMS) implementation. UK: BSI.

Kalkınma Bakanlığı, Bilgi Toplumu Dairesi. (2012). Birlikte çalışabilirlik esasları rehberi (e-Dönüşüm Türkiye Projesi) (Sürüm 2.1). Erişim adresi: http://www. Bilgitoplumu. Gov.tr/wp-content/uploads/2014/04/ Birlikte_Calisabilirlik_Esaslari_Rehberi_2.1.pdf.

Kalkınma Bakanlığı, Bilgi Toplumu Dairesi. (2014). Kamu bilgi ve iletişim teknolojileri yatırımları. http:// www.bilgitoplumu.gov.tr/Documents/1/Diger/KAMU_BIT_YATIRIMLARI_2014.pdf

Kandur, H. (2011). Türkiye'de kamu kurumlarında elektronik belge yönetimi: Mevcut durum analizi ve farkındalığın artırılması çalışmaları. Bilgi Dünyası, 12(1), 1-12.

Külcü, Ö. Çakmak, T. ve Özel, N. (2015). Kamusal Bilgi ve Elektronik Belge Yönetimi: Organizasyonlar ve Üniversitelere Yönelik Koşulların Analizi. Ankara: Türk Kütüphaneciler Derneği.

Külcü, Ö. ve Umut, G. (2014). Elektronik belge yönetimi uygulamalarında karşılaşılan sorunların analizi ve çözüm önerileri: Kalkınma Bakanlığı örneği. Bilgi Dünyası, 15(1), 102-124.

Liu, Y. (Linda). (2014). Electronic records preservation in China-An exploratory inquiry. Information Development, 30(3), 213-222.

Long-Term Storage and Migration of Electronic Records. (2015). Erişim adresi: http://web.ornl.gov/info/ records/longterm.htm.

Lyman, P. ve Varian, H.R. (2000). How much information. Journal of Electronic Publishing, 6/2. Erişim adresi: http://www. Press. Umich. Edu/ jep/ 06-02/ lyman. Html.

MacNeil, H. (2000). Trusting records: Legal, historical, and diplomatic perspectives. Dordrecht: Kluwer.

Odabaş, H. (2010). E-devletin temel bileşeni: Elektronik belge yaklaşımları ve yönetimi. 46. Kütüphane Haftası 29 Mart-4 Nisan 2010, Milli Kütüphane (s. 1-16). Ankara. Erişim adresi: https://odabashuseyin.files.wordpress. com/2011/04/okuma-metni-1-e-devletin-temel-bilec59feni-elektronik-belge-yaklac59fimlari-ve-yc3b6netimi.pdf

Önaçan, M.B.K., Medeni, T.D. ve Özkanlı, Ö. (2012). Elektronik belge yönetimi sistemi (EBYS)'nin faydaları ve kurum bünyesinde EBYS yapılandırmaya yönelik bir yol haritası. Saylştay Dergisi, 84, 1-26.

Özdemir, L. ve Cengiz, E. (2019). Türk kamu sektöründe dijital süreklilik ne kadar mevcut: Teorik bir çerçeve. B. Yalçınkaya, M. A. Ünal, B. Yılmaz ve F. Özdemirci (Ed.), Bilgi Yönetimi ve Bilgi Güvenliği: e-BelgeeArşiv-eDevlet-Bulut Bilişim-Büyük Veri-Yapay Zekâ (s. 273-294) içinde. Ankara: Ankara Üniversitesi Bilgi Yönetim Sistemleri Belgelendirme ve Bilgi Güvenliği Merkezi.

Özdemirci, F. ve Alyakut, S. (2012). Bilgi yönetimi projelerinde izlenmesi gereken yol haritası için öneriler. Bilgi Dünyast, 13(3), 557-564.

Patterson, G. ve Sprehe, T. J. (2002). Principal challenges facing electronic records management in federal agencies today. Government Information Quarterly, 19, 307-315.

Resmi Yazışmalarda Uygulanacak Usul ve Esaslar Hakkında Yönetmelik. (2020, 10 Haziran). Resmi Gazete (Say1: 31151). Erişim adresi: https://www.resmigazete.gov.tr/eskiler/2020/06/20200610-8.pdf

Sağlık Bakanlığı. (2019). Sağlık Bakanlı̆̆ı bilgi güvenliği politikaları kılavuzu. Erişim adresi: https:// bilgiguvenligi. saglik. gov.tr/ Haberler/ Detay/ 70/saglik- bakanligi- bilgi- guvenligi- politikalari- kilavuzuguncellendi 
The National Archives (UK). (2017). Digital preservation strategy. Erişim adresi: https://www. archives. gov/ preservation/ electronic-records/digital-preservation-strategy

The National Archives (UK). (2017). Digital strategy. Erişim adresi: https://www. nationalarchives. gov.uk/ documents/ the-national- archives-digital- strategy-2017-19.pdf

The National Archives (UK). (2017). Understanding digital continuity. Erişim adresi: https://www. nationalarchives. gov.uk/ documents/ information- management/ understanding- digital-continuity.pdf

The National Archives of Australia. (2015). Digital continuity 2020 policy. Erişim adresi: http://www. naa. gov.au/records- management/ digital-transition-and-digital-continuity/digital-continuity-2020/ index.aspx

The National Archives. (2002). Requirements for electronic records management systems. London: Public Records Office.

Tonta, Y. (2009). Preservation of scientific and cultural heritage in Balkan countries. Erişim adresi: http:// yunus. Hacettepe. Edu.tr/ tonta/ yayinlar/ tonta- alkan-2009.pdf.

Türk Standartları Enstitüsü. (2014). Elektronik doküman ve belge yönetimi koruma profili (Sürüm: 1.3.1), Erişim adresi: http://www. Tse. Org. tr/ upload/tr/ dosya/ icerikyonetimi/ 3507/ 170320 15094632-2.pdf

Türkiye Cumhuriyeti Cumhurbaşkanlığı Dijital Dönüşüm Ofisi. (2020). E-Yazışma teknik rehberi (Sürüm 2.0). Erişim adresi: https://cbddo. gov.tr/SharedFolderServer/Projeler/ File/ EYP_2.0/EYP2.0_teknik-rehberi.pdf

Türkiye Cumhuriyeti Cumhurbaşkanlığı Strateji ve Bütçe Başkanlığı. (2020). Kamu bilgi ve iletişim teknolojileri yatırımları raporu. Erişim adresi: http://www.bilgitoplumu.gov.tr/wp-content/uploads/2020/09/2020B\%C4\%B0T-Yatirimlari-Raporu.pdf

United Nations. (2008). E-government survey 2008: From e-government to connected governance. Erişim adresi: https:// publicadministration. Un. Org/ egovkb/ portals/ egovkb/ Documents/ un/ 2008-Survey/ unpan028607.pdf

Xie, SL. (2012). Digital records management: the lacking foundation for continuing accessibility. Online Information Review, 36(2), 299-306.

Yalçınkaya, B. (2014). E-Devlet üstveri standardının oluşturulması ve Türkiye için modellenmesi (Yayımlanmamış doktora tezi). Türkiyat Araştırmaları Enstitüsü Bilgi ve Belge Yönetimi Anabilim Dalı, Marmara Üniversitesi, İstanbul.

Yalçınkaya, B. (2016). Elektronik belge yönetimi sistemi (EBYS) uygulamalarında başarı faktörü ve fayda analizi, AJIT-e: Online Academic Journal of Information Technology, 7(23), 67-91. Erişim adresi: http:// www.ajit-e. org/?menu =pages\&p =details_of_article\&id=196

Yazıcı, S. ve Özdemirci, F. (2019). EBYS birlikte çalışabilirlik olgunluk modeli ve Ankara Üniversitesi e-BEYAS uygulaması. B. Yalçınkaya, M. A. Ünal, B. Yılmaz ve F. Özdemirci (Ed.), Bilgi Yönetimi ve Bilgi Güvenliği: e-Belge-eArşiv-eDevlet-Bulut Bilişim-Büyük Veri-Yapay Zekâ (s. 95-111) içinde. Ankara: Ankara Üniversitesi Bilgi Yönetim Sistemleri Belgelendirme ve Bilgi Güvenliği Merkezi.

Yılmaz, C. (kişisel iletişim, 31 Mart, 2017).

Yılmaz, M. (2012). TS 13298 Standardı ışı̆̆ında elektronik belge yönetim sistemleri. Erişim adresi: http:// ab. Org. Tr/ ab13/ bildiri/71.pdf 
